\title{
Do Vary of English Shows Good For the Children during Stay at Home?: A Library research
}

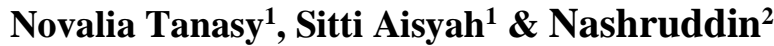 \\ ${ }^{1}$ Universitas Muslim Maros, Maros, Indonesia \\ ${ }^{2}$ STKIP Muhammadiyah Barru, Barru, Indonesia \\ novalia@umma.ac.id
}

\section{ARTICLE HISTORY}

Received : 2021-06-27

Revised : 2021-07-12

Accepted : 2021-07-28

\section{KEYWORDS}

Children's English Developmental English Shows

The Advantages

The Weaknesses

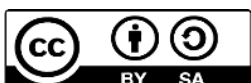

\begin{abstract}
THE ABSTRACT
Children can naturally acquire languages easily and quickly even without formal teaching from teachers. English shows provided the children new knowledges and updates without leaving the comfort of their homes due to lock down. This study was designed to analyse the use of English shows to build the children's English developmental for learning English as foreign language, including discussion of its advantages and weaknesses. Library research and qualitative method were used to explain the findings. The data collection was documented from 3 working papers, 25 journal articles and 4 renowned books related to the topics. The analysis reveals that the children were able to retell the shows scenes, characters, topics, stories, opinions and they can pronounce English words alike as the natives do. From English shows, the children can learn some positives values and habit from the characters. The weaknesses of this strategy is control means that parents must spare time to accompany their children while watching the shows which may boring and tiring them. The other weakness is cultural shock. The English shows were mostly created by American and European whom have different basic cultures from Indonesian, therefore parents must ready to explain some scenes which are unfamiliar to ours. Lastly, watching English shows from television and YouTube also considered as more expensive instead of learning from classroom since it still need payment, subscription, fast internet connection, gadget and electricity.
\end{abstract}

\section{Introduction}

By the end of 2019, an unidentified virus emerged from Wuhan, China and in short resulted rapid outbreak globally including to our country. By WHO this virus is officially named as COVID 19 (Wu et al, 2020). The disease effects respiratory infection that lead to acute complication to death. The rapid deployment had the government taking crucial decision to protect the community such as worshiping at home, implementing programs from home, early closing various places that contain crowds (café, mall, market, recreation area etc), working from home, even learning from home.

Learning from home is conducted through internet where the students following the teachers' instructions and doing their obligations independently from home and after that they are expected to keep staying at home to prevent the virus. This condition made the parents worry that their children do not get enough knowledge as their children normally had from school and thinking alternative ways to fill the gap.
Some parents choose to support their children's education by joining online tuitions, but some other parents let their children learn from television or YouTube shows to get the knowledge naturally because they believe that watching knowledgeable shows can enhance children's cognitive development explicitly, especially about language (Anderson, 2012)

Children can naturally acquire languages easily and quickly even without formal teaching from teachers. The acquisition automatically appear as a sign that their brain works normally. They have easier ways to adopt new languages compared to adults. Early childhood started at age 2 up to 5 years old is a golden period where they can develop not only physical but also cognitive, socio-emotional and soul, including language development (Winke, 2010). Previous studies and experts showed different suggestions on the exact age for children to learn new languages, but mostly they said that it is best done before they reach age at 10 (Hanly, 2012).

Teaching new language to children is different from adults since the children have unique characteristics (Hariyono, 2020). Their characteristics 
can be seen through their certain attitudes, as Syafrizal and Haerudin (2018) added that if the children like the new language learning process, they will show it through clear intention, more energic, and easier to secure themselves with the environment. In line with that, Juhana (2014) revealed that children who are attracted by the lesson process will have great curiosity and excitement to experience new things which will make them easier to absorb and understand the new language. Once they feel into the learning process, rest of it will run as natural enjoyment process just like they are playing.

Thus, Ramadhani (2019) declared that to lead children successful in learning foreign language, requires particular approach which is diverse from teaching adults because they both have different needs and visions influenced by ages. When adults see learning foreign language is a must to support their carrier and social life sectors, the children simply experience the foreign language as something unintentionally they found through activities and they feel like to try it to get involved to the activities process such as songs, games or movies (Manurung, 2016).

Anyhow, learning foreign languages is a useful asset that will change the children lives. Later on, the foreign languages can lead them to explore new places, new cultures, new people and certainly new experiences. Further, by able to master foreign languages undeniably opening new opportunities for the children in terms of good education and better employment. This is why millennial parents are working hardly to provide facilities for their children to be able to learn foreign languages. Beside learning foreign languages from formal school, parents also have option to support their kids such as informal language courses, games, retell stories, songs, television or by using gadgets.

Since Covid 19 hits this era, mostly the children are staying at home and the parents underpin their children with television or gadget to reduce the boredom. But for some moderate parents, these stuffs are not only for entertainment but also for studying. Because from those, children can access foreign shows based on foreign languages, like English. Some of the shows that introduced in English are Team Umizoomi, Blaze and the Monster Machine, Barney \& Friends, Max \& Ruby, Peppa Pig, Blue Clues, Sofia the First, Mickey Mouse Clubhouse, Paw Patrol, Dora the Explorer, Miraculous Ladybug, Bubble Guppies, the Odd One Out, Domics, Jaiden Animations, Something Else Yt, Let Me Explain Studios and many more. These shows are not only accessible on television but also on YouTube channel. The shows are very educative since they are brought with simple English, slow pronunciation but still terrific on the screen.
The English shows mentioned above are providing the children new knowledges and updates. Children will enjoy those as entertainment and education as well without leaving the comfort of their homes due to lock down. Rao (2019) mentioned that television (and any other visual platform like YouTube) is a well common and powerful medium that can be helpful to see the worldwide. These media can give children opportunities to see the new places, people, culture, languages that haven't been experienced before. While Onayasa (2004) said that motion pictures (from television or videos) are very effective in relation to build the learners positive attitudes based on the subject's instructions, Kurniawati (2016) completed it by added that any kind of video materials can be used as alternative learning media because those contain real life dialogues from proficient English native speakers which give impressive contribution to master the language. These backgrounds lead the authors aims to analyze the use of English shows to build the children's English developmental for learning English as foreign language, including discussion of its advantages and weaknesses.

\section{Review of Literature}

Plenty of studies about relationship between children's language development and English videos or shows from many resources had been done. Those studies were conducted to see the effectivity of the media to support the children in learning English as foreign language and its results. Nowadays this strategy back to the track since our activities are limited because the government apply periodic activity restriction due to the virus transmission.

In developing the language as foreign language, the children confront problem such as lack of experience which affecting the total production and typical language they learnt, also losing interest quickly and get bored easily. Those dragged the children's power of concentration in learning implicitly short (Lutviana \& Mafulah, 2017). While Lelawati et al. (2018) stated that it is not enough to have verified teachers only to teach the children foreign language, but the teachers also should able to manage the factors, techniques, and media especially in teaching children which easily lose their interest at any time.

In the other hand, Canning \& Wilson (2000) on their research result said that the foreign language learners showed their preference in learning when offered videos. For them, videos which contain visual moving objects with sound were considered more entertaining such as movies or documentaries (including English shows), if compare to conventional way like learning in the classroom. The students also feel way better in learning because they can see and hear the conversation lively. 
Almost similar, Kelsen (2009) and Silviyanti (2014) studies revealed that the learners were more enthusiast learning English supported by YouTube shows. By using shows from YouTube, the learners encountered better atmosphere which are joyful and meaningful. Further, their studies also found that this strategy is more beneficial and motivating when conducted outside the classroom (several still prefer doing it from home) because for these students this was not only learning but entertainment as well.

Kim (2015) claimed that videos (or any moving shows) are better and more effective as tool to develop language skill rather than lecture-based instruction in the classroom. She added that teachers must deal with technology and know how apply it in their teaching process. She also suggested the teachers to start using YouTube shows or contents which is suitable to the learners needs.

Tanasy (2019) on her mixed method study brought conclusion that teaching English as foreign language needs improvisation to excite and motivate the learners, do not teach them only in the classroom because it is too boring for them. She continued that the learning process may incorporate with videos or any moving visual objects because it has visual and audible feature to enrich the language learning results. Television or YouTube English shows are the kind of improvisation too that the teachers and learners deserve to consider.

Further, another research brought by Tanasy (2017) discussed English television show entitled Make Way for Noddy concluded that the use of Noddy cartoon can improve the learners' English ability and change their attitude as well into positive in learning English after being treated with several Noddy cartoon episodes. This experimental study also found that the learners' learning ability indicated a significant difference through their academic scores after being treated by this show to compare with those who just treated with conventional way.

Latest, Janah (2021) concluded that in using television shows for learning and teaching of English language and literature, there are some activities that can be done such as asking the learners to describe the plot, setting, characters, point of view, symbol, and theme and asking the students to find the language features that are probably used, such as alliteration, hyperbole, imagery, irony, metaphor, personification, simile, and many others. This strategy also boost the learners' motivation in learning foreign language, help them easier to memorize the material, and caught their interest while the learning process run even longer.

English shows, whether from television or YouTube channel are potential resources to learn as foreign language because these shows are enriched by various kind of skill, knowledge and especially new vocabularies.
Further, television and YouTube shows can be alternative choice or education medium for children without serious intention to learn English. Why English, because most of the shows used English as the language instructions. This statement is supported by Frumuselu et al. (2015), on their studies, they discovered that English shows provided on television programs are related to unconscious and nonintentional pedagogical which can boost the learners' motivation in learning English. With this incidental strategy, the children can acquire many advantages in learning English informally and enriched it by classroom environment formally to make it even more perfect.

\section{Methods}

This study attempted to analyze the use of English shows to develop the children's English aware and acquisition in learning English as foreign language. The authors conducted library research, as an investigation controlled from starting point to finish by highlighting 3 renowned papers, 25 journal articles and 4 books. This study also applied multiple theories in content analysis (CA) i.e., Hsiu-Fang Hsieh \& Sarah E. Shannon (2005) Three approaches to qualitative content analysis; Philipp Mayring (2004) Qualitative content analysis and Ellen Hijmans (1996) Logic for qualitative media content analysis: A typology To help with the interpretation schema. The findings then were explained qualitatively.

The main analysis were based its data from paper and articles from journals about learning English through various English shows, published on 2002 till 2021, analysed at Makassar on April - June 2021. As additional results, this study analized and discussed about the advantages and the weaknesses of using English shows to build the children's English developmental. Therefore, the results were presented by exploit the combination ideas from some studies carried before related to this strategy.

\section{Findings}

The raw data on this study was gathered from 3 renowned papers, 25 journal articles and 4 books regarding to the children English' $\mathrm{s}$ development. The author select these materials since all are freely to download from any search engines and authored by renowned scholars. However, during the data cleaning and underlining the aims this study's aims to draw the children's English development after being treated by using English shows, then the author based it main perspectives as it platform of thinking from five most influential ones based on the citation number. 
Table 1. The most influencing data

\begin{tabular}{ccl}
\hline Citation & Author (s) (Year) & \multicolumn{1}{c}{ Title } \\
\hline 5.962 & $\begin{array}{c}\text { Jeremy Harmer } \\
(2007)\end{array}$ & The practice of English language teaching \\
& Jack C. Richards, \\
Willy A. Renandya & Methodology in Language Teaching \\
& $(2002)$ & \\
4257 & Paula Winke, Susan Gass, Tetyana Sydorenko & The effects of Captioning Videos Used for \\
& $(2010)$ & Foreign Language Listening Activities \\
35 & Stuart Webb & Selecting Television Programs for Language \\
& $(2011)$ & $\begin{array}{l}\text { Learning: Investigating Television Programs } \\
\text { from the Same Genre }\end{array}$ \\
\hline
\end{tabular}

Table 1 shows that those five data are the highest frequency in citation. The researchers then read and identify the important content regarding to this study. Then the researchers sit together to discuss the findings as explained below.

According to Harmer (2007), English shows are the sequences of still images representing scenes in many motions with the help of the technology of electronically, then captured, recorded, reconstructed, processed, stored and then transmitted to the receivers at their places. Through this, learners feel beyond in learning and remember the language items better than learning manually in the classroom. The learners also agreed that the show they watched can be related to their real life experience and optimize the learning potential results.

While in Richards and Renandya (2002), Richard stated that learning through audio visual videos can develop the learners memory, transfer, motivation and other factors that are important in learning. This strategy successfully stimulate which serves to elicit behaviour, response and reinforcement which functioned mark the response as being appropriate and encourages the repetition of response for memorization and learning through dialogues and drills. Further, this is also associated to better behavioural and psychology in learning results production. In this paper, Stempleski also added that English shows on television (or YouTube) are one way from many to learn English which the students expect, in the other hand also to be entertained on their leisure time.

Then Winke (2010) found that by applying videos on learning process, the learners are better able to aurally recognize the new words than learners presented with books in the classroom. The selected videos give important role of attention in learning a second language. She also figured out that many of the learners' comments indicated that the videos served the function of drawing learners' attention to the new language. The using of videos seemed to help isolate what the learners perceived to be important and helped them determine what to pay attention to in subsequent viewings.

Next, Webb (2011) declared that using television programs such as video is likely to be difficult at first, but it changed and can be supportive material which able to support the learners comprehension if the learners being served with the video over and over again on the television and they are more likely to watch them regularly. He also noted that learners who learn English through watching English shows are experiencing the new language from two ways; (1) they watch the English shows altogether with the entire batch in the classroom. This way usually led by teacher or instructor where they watch the shows or programs from episode to episode (sometimes also movies of several tittles), after that they continue it by completing some activities designed earlier to support the learning process. This kind of activities are considered as an enjoyable because changing the paper-based activities usually they through. But this method proves lesser benefits in learning the new language. Anyhow it works on developing the listening comprehension along with the vocabularies. (2) the learners may watch the English shows not from classroom (maybe from their own home or studio). This option enables the students watch the English shows individually even from their room or along with their group. This way is outweighed for learners who willing to watch the English shows as entertainment, enjoy it but at the same time can absorb the knowledge. They do not see this way as a learning process which is heavier for them if they take it so. By enjoying this way, the students can keep on learning unintentionally by watching the English shows to some extended scopes.

Further, Silviyanti (2014) admitted that $76 \%$ of the learners agree that the use of YouTube was useful to make the class interesting. The first content she used was about John Foppy's daily activities, made the learners enthusiast and motivated to see the how he got through the tough life and experiences even 
without his hands. Actually John Foppy performed how he dealt with life by using difficult words in his speech, but since the learners able to see what his doing meanwhile, the learners eventually understood with his meaning. In another content Silviyanti used which was from Maria Pascal, the learners mostly laughed and entertained because Maria Pascal showed the new unique things that Malaysian people do, funny similarities that Malaysian and Indonesian people do in daily lives, and several unpredictable and interesting facts about Malaysia. Maria Pascal brought these all so well on her content that $87 \%$ of the learners agreed that learning English can be so joyful. They admitted that the way she gave her speech, singing, telling stories were interesting that the learners can learn her native accent and intonation through her content.

Another studies also contributed some results such as from Permatasari (2013) by saying that a video is one of the visual aids that can be used in learning English which can make lesson process more fun. She suggested suggest that regular viewing of English programs may lead to large incidental new language developmental progress. Therefore Kamelia (2019) on her paper also contributed that the most advantages benefit the students can acquire from English videos or shows are not only vocabulary knowledge, listening comprehension or speaking skill, but also many other aspects. The shows she attached from several resources (tivi, cassette, YouTube) become the main factor that advantageous to improve the learners English knowledge.

\section{Discussions}

English shows are included at any content produced for viewing moving scenes on a television program or YouTube channel which can be broadcasted via over the air, satellite, cable, advertisements, or trailers that are typically placed between shows. The content including variety shows emanating from a television studio stage or YouTube personal/team studio, animation or a variety of film productions ranging from movies to series (Wikipedia, 2021).

Nowadays the technology innovations develop very rapid and giving impact to the utilization of it to the education sector also very common. Television or YouTube channel also take part in giving the children lesson of new languages related to the technology by presenting supporting English shows for English developmental. By applying English shows from television or YouTube channel to support the children English developmental, parents must aware of several things and considerations. First of all, parents must have assurance that the shows are in line with the main intention that is developing the English ability. Next, the shows' content must consist of supporting knowledge in English developmental especially the vocabularies, speaking and listening. Last, the shows must be suitable with the children age, the age sections must clear to maintain the knowledge of each age levels. When these 3 first considerations are clear, then the parents can provide the shows to the children as medium to develop their English ability along with the entertainment.

From several studies mentioned before, we can see how English shows can be so beneficial to develop the learners English ability. The shows which contain audio visual content with good panoramic quality, will attract the intention to watch longer and absorb the language lessons. The shows provide real life experience, associated to better behavioural and psychology in learning results production, to isolate what the learners perceived to be important and helped them determine what to pay attention to in subsequent viewings, become supportive material which able to support the learners comprehension to learn native accent and intonation. Farther, the shows also make lesson process run more fun and allowing the learners acquire more than just vocabulary knowledge, listening comprehension or speaking skill, but also many other aspects which are efficient to improve English ability and confidence in speaking. Since the shows are interesting and interactive, this strategy can be applied to children. Because many of the English shows (cartoon or not) are considered effective to help them learning English such as titled mentioned earlier. Therefore, the English shows demanded to be useful for the children in improving their English developmental plus their confidence.

As stated before, Harmer (2007) claimed that watching English shows can optimize the learning potential results to children aged 1 year and more, but in the other hand he also strictly said that this strategy is not effective to children younger than that because those children will not get any cognitive benefit but as entertainment only. The same thing also stated by Richards (2002) that even tough English shows give better behavioural and psychological effects in learning result production else than language lesson, mostly young children see the shows as entertainment resources only, not for education, and the learning results they got are only based on incidental not intentional. Further, he also declared that watching the shows displaces the importance of social interaction. Then Winke's study (2010) emphasized that by applying videos on learning process, the learners isolate their attention to the new language and tend to copy whatever they saw from the show. But in some cases, the children cannot distinct between what they can copy or cannot copy from the shows including the rough words.

Nevertheless, Webb (2011) concluded that better understanding through English shows has been found from children over 5 years old and beyond, the shows attributed them not only new languages but also new life experience, increasing awareness to unknown things, help them to learn other's thought and see 
things from unique perspective after watching the shows continually. This mean, English shows are potentially effective to children aged more than 5 years old in relationship to improve their cognitive and language development.

Yet, English shows are only available on paid cable television program or YouTube channel which had the parents to pay extra to get those facilities. Along with that, some of the shows also require fast internet connection which is not provided in every area, for example in rural or district. The most annoying situation may happened when the children are watching the shows and in between interrupted because of the bad or slower connection, this had the children pause and wait for the show to continue again which means wasting their time and boring. If this continually happen, the motivation to learn English through the shows will fading away.

On the other hand, English shows which are carried by native speakers some time is too difficult for the newbies, like when the natives speak too fast, using difficult words, or talking in a certain accent which is too complicated for children. Solutions to overcome this matter is by letting the children watching the shows with their friends so they can help each other to understand the situations and sharing ideas.

Therefore, the most profitable of applying English shows from television or YouTube channel to support the children English developmental might be its big opportunities and advantages in learning the new language. Kamelia, (2019) stated two opportunities for students to acquire in learning language by using television or YouTube channel. (1) television program or YouTube channel functioned as a vehicle in transmitting knowledge, including in English developmental. Television program or YouTube channel give the students possibilities to access wider range of learning opportunities, easier, simpler that offer them various kind of chosen programs or shows. This can help the students to find their needs according to their necessity. (2) the English shows provided can function as stimulation to the students critical thinking which is the most promising benefit of this method. Here, the students can give their spontaneous responses while or after watching the shows programs. By doing this, they can develop their analysis and critical observation along with the other skill proficiency. (3) English shows or programs can motivate or encourage the students to expose their confidence and self-expression orally or written base. Wigren also clarified that in this method, English shows can be very crucial in sharpening the students listening skill. Therefore, by watching English shows the students can get another learning sources which valuable and skills. Last but not least, English shows is an alternative to learn new language in exciting way.
Applying the English shows as a learning purpose in developing the new language is also considered as more interesting way, more meaningful and more authentic. Miščin \& Miščin (2018) described 3 English shows that contributed in teaching English such as:

\section{(1) The Black Books (Intermediate to Advance)}

The students listened to clip based on "The Black Books" without watching the show. Then they have to guess the characters speaking, number of the characters and explaining the show plot. After completing the answer, they can watch the show containing the clip given before to check whether their answers were correct or incorrect. After that, they continue the activity by writing the show continue based on their own imagination.

\section{(2) Friday Night Dinner (Intermediate to Advance)}

This is a show about 2 brothers who usually play pranks at each other on Friday night dinner. The topic is about the brothers who tried to put profiteroles in the fridge, but their father stopped them and intentionally hiding something. This show can be played and stopped many times to encourage the students asking some questions related to the show such as "What is their father hiding in the fridge this evening?" and "Who will be accused by dropping the profiteroles?" or "What is the reason the father hiding the thing?". After that the students can answer the questions and then try to describe the next scenes and relate it to their real life experiences. Next level, the students can watch the show again and note down the expression they may hear and explaining the use. This show contains some strong language (such as bloody or damn), this is why the show is suggested for students age 15 to 18 who are not so surprised and accustomed to exposed with these kind of expressions. This activity will be ended after asking students to finish the story by writing down their experiences related to the show as homework.

\section{(3) Buffy (Pre-intermediate to Advance)}

Buffy is actually a serial, but there is a special episode entitled 'Hush' which telling that the main characters (namely Buffy, Willow, Spike and Xander) lost their voices. Hereafter they can just moving their lips or using gestures to communicate. While watching this show, students must able to guess what the main characters are trying to say. This activity are applied to several groups of students for better results where they had to determine what the characters are trying to say. Then the students must present their suggestions in a role play to make this activity even more competitive.

Looking at the shows Miščin described, we can say that learning English can be exciting by using the English shows he suggested. Therefore, authors suggested two other titles of English shows which are 
also considered useful in learning English, especially for the children.

\section{(a). Mickey Mouse Clubhouse}

The show is about

Mickey, Minnie, Donald, Daisy, Goofy, Pluto and friends' adventures. In each episode they have to solve problem which is easier by the help of some special feature namely Mousekedoer. Mousekedoer will give some clues to Mickey and friends to solve the problem. Then the audiences (children who are watching the show) can take part by guessing too. Another feature Mickey got is Mystery Mouseketool. Mystery Mouseketool presented some questions that Mickey and friends have to answer to ease their journey, here the children also can answer the questions too. Mickey also has Mouseke-ThinkAbout-It Tool and Toodles features to make the journey even fun and easier. In the middle of the show there is song that the characters singing, and this song used to play several times on several show's episode so that the children can memorize this song and understand it better.

\section{(b). Barney and Friends}

This show is about Barney' adventure (a purple and green Tyrannosaurus) with his friends namely Baby Bop (a green Triceratops, aged 3 years old), BJ (Baby Bop's brother, a yellow Protoceratops, aged 7 years old), Riff (Baby Bop and BJ's cousin, an orange Hadrosaur, aged six year old) and their humans friends. This show is very educative because each of the episode conveys educational messages and new experiences from worldwide through adventures, songs, dances and daily routines. Sometimes the characters presented silly attitude but in the end they all end up with optimism. Mostly this show is started by songs, then showing the children were doing their daily activities like at school, home, yard, garden etc. later on the children involved into a confusion of daily matter, then Barney suddenly appeared into their imagination and bring them into a fantastic journey to solve the confusion with entertaining journey and educative. In the last episode Barney and friends always sing "I love you" to complete the day experiences. This song has moral messages to keep the kids close and appreciate at each other.

English shows can be great supportive knowledge sources if parents can choose wisely the suitable shows for their children. To make the learning process flows fluently, Webb (2015) arranged 6 principles that each parent must follow as below:

(1) Parents must see the show's benefit regarding to the language learning.

(2) Parents must able to choose the right level shows for their children.
(3) Parents must consider more the shows that can improve the children's speaking and listening skill.

(4) Parents must give priority to the children's comprehension and it should increase gradually time after time while watching the shows.

(5) Parents must prepare some strategies to keep supporting the new language learning process in case the children choose another show.

(6) Parents must have time to accompany their children watching the shows, give explanation especially in the early episodes to encourage and motivate the children developing their language competence.

This study also found that unintentionally the children develop their English through the shows by watching the shows repeatedly to understand the language meaning. Then after that they need to visualize it into their real life experiences to apply the language target with their friends, siblings or parents so the new language attached longer into their memory.

\section{The Advantages and Weaknesses}

\subsection{The Advantages}

As explained before that English shows carry several advantages to develop English ability. By watching the shows repeatedly and regularly, the children can gain benefits such as retell the show's story to improve their speaking and listening skill naturally from the natives. Nicolas et al (2017) decided that young aged children (lesser than 5 years old) affected the English ability better than the older children. Syafrizal (2018) and Hariyono (2020) studies also found that watching English shows was also related to motivation of the kids to get closer more to English by reading English books. In future, this habit will influence the children's academic behaviour (including the score which is very possible higher than those children who only watch local shows), confidence and their target in learning and profession. Thus, allowing children watching English shows will lead them to higher academic behaviour and achievements.

\subsection{The Weaknesses}

Some advantages of watching English shows have been mentioned before, but actually this strategy also has several weaknesses. Nowadays we can easily find English shows for children through cable television program or YouTube channel. This means that parents must choose selectively the right shows for their children to support the English developmental. Parents must spare time to accompany their children while watching the shows, especially in the several first show's episodes to avoid undesirable scenes. This may boring and tiring parents, but very useful 
considering that children cannot decide which 1 is proper shows and which one is improper. Some English shows from television or YouTube channel mentioned earlier can be solutions for parents who cannot stay accompany their children watching the shows entire time. Those shows are very save, helpful and educated for children even the youngest ones to develop their English ability.

Tough, those shows were created by natives (American and European) whom have different basic cultures from Indonesian, therefore parents must explain some scenes which are not matching to ours, such as calling older people by their names, individualism, materialism, secularism and hedonism which is not suitable for children. Watching English shows from television and YouTube also considered as more expensive instead of learning from classroom because those need payment subscription, fast and stable internet connection, certain gadget and electricity. Anyhow, wise parents can decide what to do to support their children in learning English through English shows, reduce the weaknesses or negative impacts but maximize the advantages or the positivity.

\section{Conclusion}

Since the technology grows very fast everywhere, take the advantages of it is very common including in education world. The technology can be used in vary ways for many purposes. Using English shows to develop the children English ability is suggested by several verified studies before. This strategy enable the children learn English unintentionally along with their daily activities. The results, children will able to retell the shows scenes, characters, topics, stories and opinions. The children also will able to understand English utterances and utter those into simple daily conversation. The best part of this strategy is that the children can speak and pronounce English words alike as the natives do. From English shows, the children also can learn some positives values or habit the foreign people have such as prioritize pedestrians, prioritize people with special needs (disabled), punctuality and queue which is rare being taught by parents nowadays. Further, watching English shows can make the English learning process flows naturally, interesting and authentic.

Watching English shows regularly give some advantages to the children such as ability to retell the show's story which can improve their speaking and listening skill naturally. Children younger than 5 years old affected the English ability better than the older children by watching the shows regularly. Further findings saying that watching English shows also related to motivation's improvement reading English books. By allowing the children watching English shows will give improvement in academic behavior, confidence, target and scores.
Anyhow this method has several weaknesses. Since every child has access to find English shows through cable television program or YouTube channel, parents must choose selectively the right shows to support the English developmental. Parents also must prepare some spare time to accompany their children while watching the shows to avoid undesirable scenes, which is may boring and tiring the parents. Those shows were created by natives (American and European) whom basically have different cultures from Indonesian, therefore parents must explain some scenes which are not suitable to ours. For some people, watching English shows from cable television and YouTube also considered as expensive because those need payment subscription, fast internet connection, gadget and electricity. Lastly, applying English shows through television program or YouTube channel for children's English developmental require preparation and wise consideration before. Wise parents can decide and support their children in learning English through English shows, because not all English shows can be helpful to maximize the advantages or the positivity and reduce the weaknesses or negative impacts.

\section{References}

Anderson, Daniel R. (2012). The Educational Impact of Television: Understanding Television's Potential and Limitation. Research Gate: Book Chapter. 10.1002/9781444361506.wbiems134.

Canning, C., Wilson. (2000). Practical Aspects of Using Video in Foreign Language Classroom. The Internet TESL Journal. 6(11), 30-36.

Frumuselu AD., De Maeyer S., Donche V., Colon Plana M del MG. (2015). Television Series inside the EFL Classroom: Bridging the Gap between Teaching and Learning Informal Language through Subtitles. Linguistic and Education Journal, 10(01), 02-11.

George, Mary. (2008). The Elements of Library Research: What Every Student Needs to Know. 10.1515/9781400830411.

Hardach, Sophie. (2021). Kapan Usia Terbaik untuk Belajar Bahasa Asing? BBC News Indonesia.

Hanly, Mark et al. (2012). School starting age and child development in a state-wide, populationlevel cohort of children in their first year of school in New South Wales, Australia. Early Chidlhood Research Quarterly, 48, (03). 325340

Hariyono, TC. (2020). Teaching Vocabulary to Young Learner Using Video on YouTube at English Course. Language Research in Society (LaRSo) Journal, 1(01), 42-46.

Harmer, J. (2007). The practice of English language teaching. England: Pearson. 
Hijmans, Ellen. (1996). The logic of qualitative media content analysis: A typology. Communications. 21. 93-108.

Janah, Karunia. (2021). Reviewing the Use of Television Shows for Learning and Teaching of English Language and Literature: Potentials and Limitations. 4th English Language And Literature International Conference (Ellic), 4 (10), 76-83.

Juhana, J. (2014). Teaching English to Young Learners: Some Points to be Considered. Asian Journal of Education and e-learning, 2(01), 4346.

Kamelia. (2019). Using Video as Media of Teaching in English Language Classroom: Expressing Congratulation and Hopes. UTAMAX: Journal of Ultimate Research and Trends in Education, 01(01) 34-38.

Kelsen, B. (2009). Teaching EFL to the iGeneration: A survey of using YouTube as supplementary material with college EFL students in Taiwan. Call-EJ Online, 10(2), 1-18.

Kim, Hea-Suk. (2015). Using Authentic Videos to Improve EFL Students' Listening Comprehension. International Journal of Contents, 11(04), 15-24.

Kurniawati, Dewi. (2016). The Use of Video to Enhance the Teaching and Learning Process of Listening English for University Students. English Education: Jurnal Tadris Bahasa Inggris, 9(02), 276-289.

Lutviana, Rizky., \& Mafulah, S. (2017). The Use of Video and TPR to Improve Students' Vocabulary Mastery. EnJourMe: English Journal of Merdeka, 2(02), 89-97.

Manurung, Sulastri., \& Pohan, AF. (2019). Students' Perception on the Implementation of Video Dubbing Project in Teaching Speaking. ANGLOSAXON: Journal Of The English Language Education Program, 10(02), 288-296.

Mayring, Philipp. (2000). Qualitative Content Analysis. Forum Qualitative Sozialforschung / Forum: Qualitative Social Research [On-line Journal], http://qualitative-research.net/fqs/fqse/2-00inhalt-e.htm. 1.

Miščin S, Miščin E. (2018). Using TV Shows in Teaching English. Strani Jez, 4(7), 103-110.

Nicolas-Gavilan, M. T., Ortega-Barba, C. F., \& Galbán-Lozano, S. E. (2017). Television series use in teaching and learning professional ethics in communication. Media Watch, 8(1), 44-58.

Onayasa. (2004). Selection and Utilization of Instructional Media for Effective Practice
Teaching. Institute Journal of Studies in Education, 2(01), 128-133.

Permatasari, Dewi. (2013). The Use of Video as a Medium to Improve Students Ability in Writing Narrative Texts. ELT Forum: Journal of English Language Teaching, 2(1), 1-11.

Ramadhani, M., Bahri, S., \& Silviyanti, M. (2019). Teacher's Problems in Dealing with Autism Children in Learning Process. READ Research in English and Education Journal, 4(02), 31-35.

Rao, Parupalli. (2019). The Influence of Television Shows and Movies on Learning English in English Language Classrooms. Research Journal Of English (RJOE), 04(02).

Richards, J., W. Renandya. (2002). Methodology in Language Teaching. New York. Cambridge University Press.

Syafrizal, Haerudin. (2018). The Implementation Of Vocabulary Building Strategy In Teaching English Vocabulary To Young Learners. Journal of English Language Teaching, 5(1), 40-46.

Silviyanti, TM. (2014). Looking into EfFL Students' Perceptions in Listening by Using English Movie Videos on Youtube. SIELE: Studies in English Language and Education, 01(01), 42-58.

Tanasy, N. (2017). Using Noddy Cartoon to Improve the Writing Skill of the First Year Students of SMK Terpadu Mega Rezky Makassar. Ethical Lingua: Journal of Language Teaching and Literature, 04(02), 109-119.

Tanasy, N. (2019). Improving the Vocabulary Mastery through Word-Connection Game. ETERNAL: English, Teaching, Learning, and Research Journal, 05(02), 318-335.

Webb, S. (2011). Selecting Television Programs for Language Learning: Investigating Television Programs from the Same Genre. International Journal of English Studies, 11(01), 117-135.

Winke P, Gass S, Sydorenko T. (2010). The effects of Captioning Videos Used for Foreign Language Listening Activities. Journal of Language and Learning Technology, 02(14), 65-86.

Wu, Yi-Chi, et al. (2020). The Outbreak of Covid 19: An Overview. Journal of the Chinese Medical Association, 83 (03). 